\title{
The Populist Revolt against the West
}

\section{Alternative Paths within a Globalizing Modernity?}

\author{
Ralph Schroeder | ORCID: 0000-0002-4229-1585 \\ Oxford Internet Institute, University of Oxford, Oxford, UK \\ ralph.schroeder@oii.ox.ac.uk
}

\begin{abstract}
The question this article tries to answer is: to what extent can the recent rise of populism outside of the West be attributed to anti-Western sentiment? Interest in populism has focused on Western democracies, with far less attention devoted to regimes in non-Western parts of the world. This article takes three major cases - India, China, and Turkey. The article examines the recent intensification of populism in the three cases, but also shows how populism fits into the longer comparative-historical trajectories of a revolt against Western domination. The conclusion puts populism in a wider perspective: how do these non-Western assertions of populism shed light on debates about alternative paths within modernity and on the nature of populism in Western democracies?
\end{abstract}

\section{Keywords}

populism - India - China - Turkey - development - anti-Westernism

\section{Introduction}

The question that this paper tries to answer is: to what extent can the recent rise of populism outside of the West be attributed to anti-Western sentiment? Scholarly and media interest in populism has focused on Western democracies and there has been a recent surge of attention to the topic in response to Brexit, anti-immigrant parties in Europe, and the election of Donald Trump. Far less attention has been devoted to regimes in other parts of the world. This 
paper takes three major cases - India, China, and Turkey - and traces the current rise of populism to the assertion of a non-Western political project. The recent intensification of populism in the three cases, since the end of the Cold War, fits into longer-term trajectories of a revolt against Western domination. There are lessons from these three cases for the current dysfunctionalities of Western democracies: populism in Western democracies has similarly been based at least partly on a re-assertion of Western 'civilization' aimed against rivals, such as the threat of Islamism and of Chinese economic competition. Both the commonalities - anti-elitism, ultra-nationalism, exclusionism - and the varieties of different types of populism, are catalogued. The conclusion examines how non-Western revolts fit into a larger debate about a globalizing modernity: in what sense are the non-Western populist paths alternatives to Western democracy, and if so, how do they shed light on departures from - or variations within - modern social and especially political development? The conclusion also points to the tensions within rising populisms, including in Western democracies, as well as the potential forces that can counteract them.

The article will proceed as follows: first, it will define populism and provide a general account of its recent resurgence. Next, it will focus on the characteristics of the three specifically anti-Western features of cases of populism outside the West. At this point it will be useful to give a brief account of each of the three cases. Then the article turns to comparisons with Western populisms and how non-Western and Western populisms mirror and depart from each other, and to the implications that can be drawn from these comparisons. The conclusion will assess the extent to which populism is part of a wider globalizing pattern and reflect on the relation between populism, authoritarianism, and democracy.

Before proceeding, it will be useful briefly to clarify the language of 'Western' and 'non-Western'. These terms are used here because non-Western populists themselves and scholars analyzing the phenomenon use this terminology. Indeed, the title of this essay borrows from two important publications on the topic (Aydin 2006; Mishra 2012). Other designations, such as high- versus lowincome countries, or the Global North and South, might be more appropriate, but social science must also follow the language deployed by political actors themselves. The revolt against 'modernity' could be used, but the viability of democratic and authoritarian paths will be discussed in the conclusion. In any event, an argument will be made shortly about how modern politics differs from pre-modern politics in terms of a 'progressive' struggle for citizenship rights. Other aspects of modernity, again discussed in the conclusion, include increasingly disembedded markets and growing techno-scientific control. 
Modern can also be seen as 'progressive' in contrast with pre-modern societies, but modern technoscience has also destabilized the natural environment, and disembedded markets have resulted in economic instabilities and new inequalities, and there are specific reversals to the expansion and deepening of citizenship rights, which are being pushed back against. In other words, 'modernity' is used here without associating the term necessarily with 'progress'. But the progress of citizenship rights and potential reversals to it also lie at the heart of the account of populism here, to which we can now turn.

The definition of populism that will be used in this article is Mudde and Kaltwasser's (2017) much cited threefold one whereby populism is anti-elite or anti-establishment, prioritizes the will of 'the people' seen in exclusionary terms, and seeks greater power for the 'general will' or of 'the people'. The difference between right-wing (exclusionary towards outgroups and against established political elites) and left-wing populism (with an exclusionary economic anti-globalism and against globalizing economic elites) can be left to one side here: as we shall see, there are elements of both in all three cases that will be examined. Also left to one side will be whether populism is a 'thin' ideology; at least in the cases of India and Turkey, where Modi and Erdogan have been in power and governed with a range of populist policies for more than one term, so it seems that this ideology has become 'thick' than 'thin'. There is a range of other instances where populists have promoted and implemented strong and extensive sets of beliefs, which suggest 'thick' (see also Schroeder 2019). Support for 'thick' also comes from Hadiz (2016), who details a number of Islamist cases where the strength and ideological fervor of populists has grown, even if the share of power varies among Islamist states. The case of Chinese populism, as we shall see, is different, since this consists primarily of a several protest movements, though these are based on long-standing ideologies, and it is mainly confined to elites but also resonates among a wider group of ultranationalist and 'leftist' or 'red' supporters. So, to be clear, this is not a case of a populist regime but rather of strong social forces within an authoritarian society (where anti-elite forces are kept at bay). Again, we will need to come back to this point and to the issue of the strength or 'thickness' of populism in the conclusion.

The causes of populist resurgence also vary, but two common explanations based on economic or cultural factors will not be emphasized here: The first is culture or identity and related to migration or ethnic tensions (Fukuyama 2018; Norris and Inglehart 2019). As we shall see, these are not the main issue in the three cases here, though they no doubt play a role. Nor is the explanation here based on economic forces or neo-liberal capitalism, the 'losers of globalization' 
thesis (Judis 2016; 2018). Though growing inequalities no doubt play a role, the economies among the three cases have had ups and downs in recent years, and anti-Western populism is strongest among their elites. Instead, the explanation here is a political one, based on the trajectory of the deepening and broadening of citizenship rights (civil, political and social, developed by T.H. Marshall) which has characterized recent history (Turner 1986; Mann 1988, 2013). This expansion of citizenship rights has recently come under strain: with increasing demands on states to provide more welfare services for growing numbers, even in states with expanding economies like those of China and India and Turkey, these services (education, health, pensions) can no longer be expanded as they have in the past. Hence the call to restrict and expand them only for certain 'people', excluding 'others'. These are the long-term roots of populism in many parts of the world (Schroeder 2020), though populism has had little resonance in some parts of the world (for example, Ireland, Japan, and Singapore, to mention just three). The focus in this article using this explanation is on antiWesternism, or populism directed outwards but also inwards against elites that do not cater enough for their own 'people'.

Before we begin, it may be useful to contrast the argument with two others: One is the debate that took place in the 196os whereby, in several contributions to an early seminal volume about populism (Ionescu and Gellner 1969), populism was seen in terms of an agrarian revolt against modernization. 'Modernization', again, is a topic we will need come back to, but the cases examined here do not look backwards towards a cohesive rural past (though they seek to strengthen cultural traditions) but rather look forwards to a future after the eclipse of Western domination and triumphalism. Second, the argument is quite different from Huntington's (1996) "Clash of Civilizations"; there is no suggestion that either anti-Western populism is a driving force of a reconfiguration of the international order, nor that the various assertions of greater power aim at wider domination: apart from strengthening regional power, the 'my country first' worldview among the three cases here does not seek to assert primacy over other civilizations but merely to achieve recognition as a viable path of development (though it is true that there is a fringe among these populisms, as among Western ones, that seeks to not only defend but also expand cultures, but these are fringes).

There is, however, a connection with the global order insofar as the populisms examined here are not just a reaction against the West, but also a result of the shift from global bi-polarity to what Mann (1986:27) has called a multistate civilization (in contrast with dominant empires). Similarly, Bayly (2018) has dated the reaction against the West from the fracturing of the world order 
with the onset of neoliberalism. Yet the main caesura for the purposes here can more usefully be seen as the end of the Cold War, when there was a shift away from two global powers towards a world no longer dominated by the contest between two main rival developmental paths (Westad 2005). The geopolitical environment is thus set on a path towards encouraging greater ultranationalism - 'ultra', to set this nationalism apart from 'classical' nationbuilding which did not necessarily have external enemies (more on this later) - insofar as the allegiances to the global bipolar ideological rivalry are waning. Still, it is worth pointing out that for the foreseeable future, while the world order may reflect different developmental paths, the US will remain a military hegemon and the US and China (and EU) are geo-economic rivals. Yet the populisms catalogued here are 'from below' and nationally caged (again, departing from Huntington's argument).

The argument in this article is that the explanation of the contribution of anti-Westernism to populism rests on two other factors apart from the contribution of this geopolitical shift: the degree of repression from above, and the struggle against this repression from below in the ongoing struggle for citizenship. These factors make for a strengthening of populism in the three cases, but repression from above and struggle from below in the three cases (and more generally) are a result of how the state's resources are increasingly constrained, as already mentioned, which is a general phenomenon with specific variants: elites are regarded as unresponsive to 'the people's' demands under conditions of constrained expansion of citizenship rights. And, to anticipate, there are, of course, also grounds for a weakening of populism: not just economic growth which enables greater expansion of citizenship rights, but also increasing secularism and cosmopolitanism or weaker attachment to ethno-religious identity which allows for greater pluralism, as well as the increasing spread of consumerism and rising trade volumes in more open economies, technoscientific progress, and infrastructurally as opposed to despotically stronger states (again, borrowing Mann's concepts, 1986, 2013) which make for more secure rights. Against this backdrop, we can examine the three cases in detail.

\section{$2 \quad$ China's Fragmented Anti-elite Revolt}

Before discussing the Chinese case, a word of caution is necessary: China is not normally considered populist since two features of populism - antielitism, and exclusion of 'others' - are not dominant even if they are strong social forces. In particular, criticism of the party-state's elite is not generally 
tolerated in an authoritarian system and migration and ethnic tensions do not play a central role (except on the fringes in relation to Tibet and the Uighurs). On closer inspection, however, criticism of the party elite and a sense of the superiority of Chinese civilization to the exclusion of 'others' can be found. It is, however, latent and fragmented since open and large scale coordinated protest in China is repressed by the regime. Yet, as Wright (2018) points out, of the several main forms of protest - environmental, worker's rights, ethnic and religious, human rights and democracy - it is nationalism (or here, 'ultranationalism', see below) that is most tolerated or least repressed in China. That is partly because this kind of protest aimed against the regime also strengthens its agenda of unifying the country - as long as its ultranationalism does not force the regime to go 'over the top' and against its own more moderate foreign or domestic policy. If the regime can 'keep the lid on', this type of 'grassroots' populism is therefore likely to continue to play a major but dormant role. In fact, the populist revolt in China, as in the other two cases, is not only 'grassroots' but mainly driven by political activists and intellectuals. But the populist movement in China also has different versions: those harking back to a great Confucian past, those harking back to the greatness of the Maoist period, and nationalists asserting the superiority of Han culture. All three seek to prioritize the rights of those who are seen to have contributed to China's unique rise and to exclude others.

Chinese nationalism - or here mainly 'ultranationalism' (Zhao 2004) which can be defined as assertion being directed against internal and external enemies - has come in several varieties. In terms of anti-Westernism, a turning point in the debate about its orientation towards the West was the May Fourth Movement in 1919 (Mitter 2004: 3-25). A Sino-centric versus a Westernizing path have tussled ever since. This is of course a simplified picture, but it is also necessary to distinguish between various elite and intellectual 'sides' in this debate, in contrast with a more general popular rising patriotic tide strengthened by China's growing economic prowess. Consumerism, for example, has also been couched in nationalistic terms (Gerth 2010). Yet the recent Chinese wave of anti-Westernism or anti-Americanism can be dated to the 199os with the bestselling 'China Can Say No' books (Fewsmith 2008: 159-62). The debate about the aggressiveness or otherwise of Chinese nationalism continues (Gries 2004; Weiss 2019), but to qualify as populist, ultranationalism must go beyond nationalism and have internal and external enemies. One example that combines both is the disparaging of those who sympathize with the 'White Left' (baizuo), the liberal (in the American sense) multiculturalists and cosmopolitans who are generous towards foreigners and undeserving populations 
within China, and which Chinese populists are particularly fond of attacking (Zhang 2019).

There are several other factions who call for the regime's elites to put China's interest first externally and to reward those who have made China great including, again, Han nationalists, Maoists, and Confucianists (for populism reviving Maoism, spearheaded by Bo Xilai, see Junker 2021; for various elite factions, Shi-Kupfer, Ohlberg, Lang, \& Lang 2016). They only partially overlap with those who seek a greater flexing of Chinese military muscle since the regime's geopolitics are separate from challenging the legitimacy of the regime, which Xiang (2020) argues has been a central and long-standing tradition in China: he says that is how the people, on the basis of a morally grounded idea of legitimacy (as opposed to a transcendently religious or transcendently democratic one) have always judged and challenged their rulers (the emperor, or now the party and its leader) based on deeds rather than a transcendental standard. This notion of legitimacy, he argues, is not in competition with Western democracy but rather widely accepted. Tang (2016) similarly charts how mobilizing the people on behalf of the regime has underpinned its legitimacy, though this mobilization, as we have seen, can also be a two-edged sword when it pushes the regime beyond the direction it seeks to go.

\section{India's Majoritarian Hindu Extremism}

After independence, India's political options were partly shaped by the Cold War, but Nehruvian and Gandhian thought was also the basis of the political dominance of the Congress party, which lasted into the 199os. Congress built albeit uneasy - alliances across the Hindu/Muslim divide and various caste or class divides. Then, in the early 199os, Congress also set the country on a path towards liberalizing the economy, well before the Bharatiya Janata Party (the Indian People's Party, or BJP) started making electoral gains in the late 199os. But a 'saffron wave' (saffron, the colour of Hindu nationalism) followed the riots surrounding the Ayodhya temple dispute in 1992 and Hindu ultranationalism has become stronger ever since (Hansen 1994). Some have traced the populist appeal further back, to the direct appeal to the 'the people' outside of the party during Indira Gandhi's 'emergency' government in the late 1980s (Kenny 2017). And Modi can also draw on an intellectual lineage for his ultranationalism further back during the 1920 and 3 os when the ideas for a Hindu nation were articulated by Sarvakar and others (Jaffrelot 2016). 
But Modi's populist anti-elitism only crystallized when he challenged his own party establishment to become candidate for prime minister during the 2014 election. His outsider campaign was successful and he has since been able to entrench his position with the election in 2019. Both elections were centered on his personal appeal and leadership rather than on the BJP as a party. His campaigns have also been focused on the parts of the population that use Hindi and other vernacular languages (Neyazi 2018), deliberately attacking the English-speaking urban elites associated with the Congress party. The Congress party is also accused of corruption, of being a partly foreign (Sonia Gandhi, for many years the leader of the party, is Italian born) political dynasty, and of favoritism towards minorities, and especially Muslims.

India's anti-colonial struggle has shaped its anti-Westernism, but populism here is also a post-colonial 'local' assertion against a modernizing and cosmopolitan elite that is responsible for secularism and 'liberalism' in the American sense. India's elite intellectual institutions - the media, the universities, civil society NGOs and think tanks - have been dominated by secular left-leaning progressives, though the BJP has tried to create rival institutions on the right, partly via the Rashtriya Swayamsevak Sangh (RSs), its paramilitary volunteer organization (Andersen and Damle 2018: esp.63-91). India's populist revolt is thus not so much anti-American but has become anti 'liberal' and anti-secular. Nor is it simply looking to the past: Hindu ultranationalism has an affinity to Gandhian self-reliance, but Modi also seeks a high technology future ('digital India') and at least regionally a strong military role. But populists hate Indian intellectuals: Mehta says there is a 'backlash' against them from side of 'Hindu nationalists' who accuse them of 'imposing Western values on Indian civilization' (2019: 78). Indian intellectuals have had weak institutional bases (chiefly the universities and NGOs, now under attack by Modi), which is different from China but with similarities, as we shall see, with Turkey: in China, rightwing or ultranationalist intellectuals are in a strong position and so are those who seek a return to the Maoist past (and so are leftist elites in China), but in Turkey, Islamist clerics and their control of schooling have occupied a central institutional role in upholding devoutness. But populist thinkers in all three cases oppose development based on Western values.

One further aspect of Modi's appeal deserves highlighting: his developmentalist agenda. Though Modi is sometimes seen as right-wing economically, based on this time as chief minister of Gujarat, his time as prime minister has sought to extend the government's economic benefits to a wider population and to focus on infrastructure development (Chatterjee 2020). Hence too his support among voters, which in 2014 came primarily from the upper castes, 
has widened to the rural population in 2019 (Mairano 2019). Even if economic inequalities did not diminish during his five years in office, and even if the benefits bestowed via his government were often less than what they were made out to be during his campaigns, it is nevertheless the case, as post-election surveys show, that he was seen as responsible for making the poorer better off. Jaffrelot has summarized his appeal as follows: 'Modi is perceived by the poor, not only as one of them who is defending them against the rich ... but as a man they can trust and who cares for them ... Even if they have not benefitted from his largesse, they think he will deliver through these highly publicized centrally sponsored [welfare] schemes which are closely associated with him. They also see him ... as the strong man India needs to protect their country against the external threats' (2019: 158). His populism thus goes beyond traditional caste and left/right divisions.

\section{4}

\section{Turkey's Islamist Turn}

Turkey has similarities with India and China inasmuch as its anti-Westernism harks back to the glory days of the past; in this case the Ottoman empire. But like other late-modernizers, such as Japan, with which it is often compared, Turkey also had a Westernizing drive during the 19th and much of the 2oth century, reaching its peak with Kemal Ataturk's efforts to create a secular and democratic republic. Even in recent times, when the possibility of accession to the European Union was at its height (2002-2007), Turkey was seen as a beacon of secularism and democracy - a commonly used phrase is that Turkey could act like a 'bridge between East and West' (Tugal 2016:1) - when other countries in the region were seen as going in the opposite direction. But a government led by Recep Tayyip Erdogan's AKP (Justice and Development Party) has now been in power since 2002 and its Islamist politics have become ever more pronounced. As we will see, this populist backlash shares key features with India and China, including a rejection of external Westernizing forces and domestic anti-elitism combined with bottom-up exclusionary politics.

Erdogan's current efforts to reassert Turkey's great power status looks back to when Constantinople was at the heart of the Ottoman empire. But the competition between the Ottomans and the Russian and Habsburg empires led to modernization attempts in the 19th century when Islamist and nationalist identities became more closely entwined. Barkey (2008) has shown that before the 19th century, there was much toleration for other faiths in Ottoman lands. But in the later 18th century, economic inequalities between religions 
crystallized, and with it distrust and emnities between religious communities and also increasingly ethnic identities. Throughout the 19th century the Tanzimat reforms that reshaped the empire into a Turkish nation-state sharpened conflicts over citizenship. After the First World War, the nationalism of the Young Turks resolved these conflicts by declaring a secular republic. In this period, as Lieven notes, 'the empire was identified with backwardness and weakness, the nation with modernity and pride' (2002: 356). But while the Young Turks and Ataturk's republicanism have been seen as a fundamental break with the past, there is now growing agreement that at the non-elite level, religious identity persisted. Put the other way around, the populist versus nonpopulist divide has deep historical roots in Turkish society.

Kemalist reforms were top-down. Bayar argues that even during the Republican era, the political elite blamed 'Ottoman cosmopolitanism' for the collapse of the empire (Bayar 2019: 86). The military sought to impose a secular bureaucracy on society from above, with mixed success, as evidenced by the repeated military coups in the post-war era (four between 196o and 1997) and the continuing role of the military to the present day (Kandil 2016). Yet the weakness of democracy is mainly due to countervailing forces from below, and, according to Baykan (2021), especially the absence of broad-based left or working class opposition. But the urban left has also been regarded as antireligious and pro-Western and associated with professionals and intellectuals, which have provided the main opposition to Erdogan. It can be added that the rural basis of Turkey's populism is now numerically most strongly represented among rural migrants to urban centers, where Islamist organizations have taken on some of the functions of civil society.

The strongest challenge against Erdogan's increasingly repressive government came during the Gezi protests in 2013. His anti-elitist populism has suppressed this domestic opposition, but his anti-elitism is also directed against anti-religious foreign elites that deny Turkey its rightful place as a great power. Erdogan has thus blamed protests on foreign governments and their conspiracies while 'claiming the leadership of Muslim peoples against Western hegemons' (Altinordu 2021: 85). Turkey's foreign relations are complex since, as Cagaptay (2020) has shown, Erdogan is dependent on the West for military support and on the EU for trade. Yet Balikci (2018) has charted the increasing hostility towards the external imposition on Turkey of Western-led economic policies which Erdogan denounces as being against the will of the people.

Erdogan's populism, like populism in China and in India, thus has an inward and outward dimension. His increasingly authoritarian Islamist politics, Kuru (2019) argues, can be seen as continuous with a long-standing suppression of 
intellectuals and a business oriented bourgeoisie by the combined force of rulers and Muslim clerics. Erdogan has bolstered his legitimacy and political Islam by shoring up support via clientelism and reshaping the welfare state by making citizenship dependent on faith (Rogenhofer 2018). He also weakened the autonomy of the media. His religiously based ultranationalism rejects foreign economic elites and aims to make a Turkey a great power in the region, and especially in the Middle East, East Africa and Central Asia (Cagaptay 2020). This is a major reversal from the recent period when closer ties with the European Union were on the cards, but many now see the rapprochement (in 2002-2007) as a strategic ploy on Erdogan's part to weaken his domestic secular and Gulenist opponents. The difficulty for Erdogan is that his Islamist leadership is held up to a standard that goes beyond the practicalities of national governance and rather to an adherence to piety within the family and parts of civil society. As Lindholm notes about Islamist leaders generally, although the pious have been seeking a 'redeemer' who will restore the rule of religious law, 'the quandary remains: How could anyone be certain that someone claiming to be a religious leader actually is speaking for a higher power, and not personal interests?' (2002: 270).

Comparisons with Western Populisms, and Conclusions

Against this account of three cases, two interconnected questions can be tackled that arise in making comparisons with populisms in Western democracies which have already been touched upon in passing: one is whether populism is democratic or anti-democratic, and the second is whether populism points to processes that are occurring worldwide or if the 'revolt against the West' points to diverging political paths? As for the question about whether populism is a threat or a boon to democracy (Pappas 2019; Mounk 2018; see also Przeworski 2019), Mudde and Kaltwasser (2017) argue that it can be both. To start with, if the definition of democracy includes not just elections and representation but also individual rights or plural institutions under law, populism mainly falls foul of these criteria inasmuch as rights are specifically denied for those subject to 'exclusionism'. In other words, populists aim at the exclusion of 'others', though the extent to which this is put into practice varies in the cases here. What anti-Western populists share is a rejection of universal human rights as a global yardstick that supersedes the powers of their states. Curiously, this rejection is also shared by a fringe among Western populists who deny that universal human rights should supersede the ultranationalist will of 'the 
people' in matters of international justice (this fringe uses the denial of human rights against women's rights, LG BTQ rights, and to protect other conservative cultural values). But what anti-Western populists also share is a rejection of what is seen as an 'amoral' or purely rule-based or procedural and institutional Western legitimation of politics.

This rejection fits with the overall shift away from a bipolar order towards a multi-civilizational world order discussed earlier: If there is no Western or cosmopolitan global 'apex', then democracy can be interpreted in ways that impose a civilizational (India) or religious (Turkey) or communitarian moral (China) order upon society. But the question mark in the subtitle of this article also asks about the viability of these 'revolts' or alternative paths: are the paths that diverge from Western democratic models feasible options for socio-political development? Before answering this, it can be noted that all paths of social development, including Eastern and Western ones, and their current legitimations, have inbuilt tensions or limits, so there is bound to be continuing conflict within an overall globalizing pressure for responsiveness 'from below'. And apart from this common political pressure, in the economic sphere, what populisms share is economic nationalism, though with variants: Only in the case of China and the US has a direct antagonism ('trade wars') been mobilized. Modi's India and Erdogan's Turkey mainly seek greater economic autochthony. And even if, as Mudde (2007:119-37) points out, European (and also American, not discussed by Mudde) populists do not have clearly defined economic policies, they share economic protectionism and welfare chauvinism (Ivaldi and Mazzoleni 2019).

But there are differences: Politically, all populists reject elites, but as mentioned, Chinese populists reject corrupt economic elites in contrast with Indians' rejection of corrupt political (or clientelist) elites and Turkish populists' rejection of secular cosmopolitan ones. And as mentioned, European populists reject economic elites in the case of left populists and cosmopolitan elites in the case of right populists, but European populists are less virulent than American Trump supporters whose rejection of politicians have had a moral tone, reasserting America's greatness. All three anti-Western populisms share an anti-elitism aimed against a cosmopolitan, Western, materialist and consumerist elite. And another similarity they share is that 'the people' are conceived in an egalitarian way: populist Islam is about inclusion from below but also a reaction against progressive cultural elites. And the legitimacy of Islamic rule rests on the virtuous community of believers, just as in China and in India there is a moral or religious 'people' that supports only rulers who adhere to the law (in a broad sense). Unlike the other two cases, however, for 
Turkey's populists the external enemy is not just the enemy of the nation-state, but also those who threaten the community of believers from without. But in all three cases, the populist backlash is against the West and its culture and its cosmopolitan cultural elites; not against mass modernity: in fact, all three countries seek high growth economies and leadership in technological innovation. And in the West too, populism is aimed against the cosmopolitanism of elites and in favor of stronger cultural identification against open borders.

Culturally, the exclusion of 'others' takes the form of primarily being aimed against Muslims (or non-Hindus) in India, against non-believers within Turkey and on its borders, and against the undeserving who have not contributed sufficiently to China's rise. A different variant of undeservingness applies in the US, where this category of exclusion applies to those who are perceived not to make an economic contribution (in China, it is more of a moral contribution). And in Europe, exclusion is primarily directed against immigrants. Further, as has been mentioned, ultranationalism generally is directed against the perceived decline of American and Christian Europe and against those who would deny the rightful rise of China's global and of India's and Turkey's regional role.

This last comparison points a broader contrast between Eastern and Western populisms: the denial of an Eastern rightful rise entails that local corrupt elites are in cahoots with a cosmopolitan elite that also suppresses the unique and divergent developmental paths sought in China, India and Turkey by virtue of prioritizing a more Western one. Along similar lines, Western populists blame multicultural elites for denying the uniqueness of a Western developmental path. But this contrast also highlights that 'rise' and 'decline' deny different rights: in the West, populists primarily focus on inclusion or exclusion of social rights since these rights have been well-entrenched in welfare states (even if, in the US, the very existence of a welfare state is curiously not well-established in the public mind). Yet in India, China and Turkey, welfare rights are more nascent and subject to contention, whereas it is more important to seek political and civil rights among those who should be rightfully represented in the polity. In other words, the difference between these rights pertain to the process of securing rights and the barriers to extending these rights that populism is a response to. These barriers have become increasingly evident over the long term of relative economic stagnation subsequent to the postwar 'golden age' in the West, accelerated by financial instability following the financial crisis of 2008/9. Quite differently in China, India and Turkey, which have seen a relatively dramatic economic transformation in recent decades which has simultaneously surfaced the divides not so much in welfare benefits but in how certain strata benefit from holding political sway. 
All three revolts are spearheaded by elites and yet against existing elites, but this circle can be squared: elites that are opposed to other elites can only come to power or stay in power with mass support. The approach to populism developed here, that populism can be seen as part of a broader pattern of democratizing states 'from below', has the implication that majorities that demand more power from elites are a democratizing force but also a problematic version of democracy. Problematic, because the implication of a drive for democracy from bottom-up forces that demands more power for 'the people' aims only partly at democracy (representation for a majority) insofar as it denies power to other parts (exclusionary majoritarianism - taken to its logical conclusion - denies party competition and the rights of minorities). Democracy as greater responsiveness therefore includes potential forces that are inimical of democracy.

The seeming contradiction here disappears when we think of how 'the people' as imagined by Chinese, Indian and Turkish populists actually came to rule in a representative democracy, as they currently do only in the very imperfect Indian and Turkish parliaments - if democracy is defined, for example, with Przeworski as 'control over governments changed as a result of elections at least twice without their result being resisted by force' (Przeworski 2019: 25). If such a democracy somehow came into existence in China, then the rights of certain groups (Uighurs, multicultural elites and elites seeking multilateralism in foreign policy) would nevertheless be thwarted if populists had their way (in China, as mentioned, populism is latent and immigration is not a strong issue, though even in this case, this kind of exclusionism is emerging, as in a recent wave of protest against giving more rights to highly skilled foreigners, see Economist 2020). Similarly for Turkey and other Islamist states or for India and their denial of the rights, among others, for secular groups or of other faiths. Bayat points out that 'the question is not whether Islam is or is not compatible with democracy, or by extension, modernity, but rather under what conditions Muslims can make them compatible' (2007:4). Note, however, that Przeworski argues that many democracies, including Western ones, are currently headed in the direction of being undermined in this way and in other ways (as we have seen in relation to pluralism and liberal individual rights), especially in countries like the US during its recent phase with a populist leader.

As mentioned, Chinese populism goes in the direction of democratizing pressure in the face of an authoritarian system where this pressure is also potentially anti-democratic insofar as it promotes exclusionary majoritarianism. But of course in a non-democratic China, populism is not in power, unlike in the other two cases. It is not clear if it could be, though it currently poses 
challenges for certain aspects of the party-state. This contrasts with some democratic states where populism has already been in power, and where exclusionary majoritarianism is partly anti-democratic because it denies democratic representation to particular groups. Populism is thus democratic in certain respects (seeking more power from below) and undemocratic in others (seeking to deny representation to all except 'the people'). The question whether populism is anti-liberal is also not clear cut: Partly anti-liberal, because again, it denies democratic representation to certain minority groups and their human rights, but it can also co-exist with these as long as their rights remain intact in practice even as populists continue to push against them. Similarly with whether populism is anti-pluralist: it is - insofar as, in practice, it denies the multiple institutions or the separation of powers in a representative democracy, but it can also exist alongside these plural institutions.

All this can be put differently: populists seek to deny power to all except 'the people', but as long as this is done within a democratic framework, this effort is contained by the competition for votes or how the representative share of populist power is translated into practice - both of which can continue to challenge liberal and plural institutions even as these institutions keep operating. In other words, democracy remains the super-ordinate principle of the modern state, with pluralism and liberalism the subordinate features of democratic states that attaches to particular parties or to certain democratic institutions. The implication is that democracy can contain exclusionary majoritarianism; it sets bounds to populism and to the alternatives paths it seeks to take, both in non-Western and Western settings. The revolt against the West thus also sheds light on Western states; it crystallizes what is democratic and anti-democratic in all modern states, Western and non-Western, and democratic and authoritarian: namely, their claims to responsiveness.

Still, in political systems with weak competition (or, at the extreme of China, no competition) for votes that are leader- or majoritarian-centric, there is more pressure than in multi-party democracies to give in to populist demands in order to obtain short-term electoral advantages. More pressure, because the pressure is not diffused among several parties or over election cycles. And these pressures can lead to illiberal, anti-pluralist and anti-democratic outcomes. Nevertheless, such attempts for opportunistic gains in legitimacy are inherently limited since these demands must then be fulfilled, and in this way, too, the alternative paths sought by populists are constrained within a range: of clientelism towards certain groups, or in systems with howsoever weak party competition - by means of compromises between parties. Put differently, the limits to populism are that populists must, in democracies, attract 
enough voters to maintain majorities or shape majority alliances (though not in authoritarian systems; yet even these systems are subject to pressure from their populations). In other words, populists typically outdo their competitors to promise more to an exclusionary 'people', which is a departure from traditional left (redistributive) and right (a lesser role for the state or a conserving one) politics. But it is a responsive politics nevertheless.

In relation to 'multiple modernities' (Eisenstadt 2020), this article has suggested that populists' aim at alternative paths could be seen to multiply modern developmental paths. But there is a difference between revolting against the West and alternatives to modernity. Modernity conventionally consists of economic, political and cultural/ideological systems (or powers) within the social order. Apart from politics, disembedded markets and technoscience are the other two powers or parts of the social order and these are not centred on the state but instead supra-national, so they may not be entirely constrained by populist politics (Mann 1986; Schroeder 2013). But politics (apart from geopolitical or military power, Mann 1986) is tied to the constraints of a state-centric system, so the alternatives to the West promoted by populists are confined to the modern state (El-Amine 2016).

In terms of a modern political project then, these 'alternatives' are: first, in China, a hierarchical communitarianism based on a morally superior civilization within a single party state. But like the other two 'alternative' projects, there are also limits to populism in this case whereby, if populist ultranationalism goes against the party's control, it will be suppressed: populism remains latent. In India, the populist alternative to the West promotes a religion-based civilizational ultranationalist agenda that dominates its democracy. The barriers or limits in this case are other parties and the constitution. As Chatterjee points out, the BJPs continued dominance depends on maintaining the support of the electorate (2020: esp. 110-11). India and Turkey are (albeit) imperfect democracies, but Chatterjee says that this limitation of populism also applies in Western democracies. In Turkey, the populist 'alternative' of a state dominated by a party that relies on support from clerics and pious voters is limited by more secular parties and their largely urban professional supporters and the courts and the military. Here we can also think of how, in the US, the constitution and competition between the two traditional parties set limits to Trump's populism, and in Europe, how compromises with other parties in multi-party parliamentary systems have done so.

While populists thus seek exclusive rule for 'the people', this still entails responsiveness from state elites competing for a share of rule for the people not a tyranny of the majority. In other words, populist ideology concerns which 
groups should benefit from state power and which should not, and the push for responsiveness from below seeks the transformation of politics - not of the whole of society or of modernity which also includes markets and technoscience. It needs to be added that the sometimes anti Western rhetoric of non-Western populists can make it seem as if Western society is rejected as a complete 'package', and this includes market consumerism and technoscience. But populists in Western democracies also sometimes reject climate science or secular education, politicizing them, though perhaps again, they do not reject the 'package' as such. In any event, a wholesale rejection of modernity inflates the populist agenda unnecessarily.

These considerations also lead back to the question of 'thick' ideologies: all three cases here have a religious or moral or civilizational basis and promote alternatives to Western democracies on this basis. These alternative visions make them into political projects and in this sense populism is not parasitic on other (thicker) ideologies: there is a political agenda for inclusion of the virtuous people to give them greater political rights and to exclude 'others'; whether this aim is achievable in the longer term remains to be seen. In any event, the implication is that these revolts are viable paths for now. But the same applies in Western democracies, where the viability of populism as a distinctive political project remains open. As argued here, this political project can be separated from economic and cultural (including techno-scientific) forces, which are more global and orthogonal to this political project - though if populism persists, economies and cultures will be shaped more nationally, and techno-science may be affected by the anti-technocratic strand directed against cosmopolitan elites. But it is politics that is potentially fundamentally reshaped beyond left and right.

Against this background, we can turn to how East-West comparisons and how populism can potentially be counteracted. The account presented here is state-centric and in line with Mann's idea that citizens have become increasingly nationally caged - unlike, say, large corporations. Yet populism pushes this caging in a new direction, towards a more exclusionary caging. Can steps be taken to make these cages more just and less exclusionary? First, the regimes discussed range from a fragmented democratic (US) to an authoritarian party state (China), but all must be responsive to 'the people'. But the populist demand for exclusionary citizenship can be countered by deepening and broadening - and in that sense universalizing - citizenship. This extension of citizenship comes up against resource constraints, but the state's resources are not necessarily zero-sum and can be redistributed or redirected. But 'universalizing' citizenship must also go with rather than against the grain of political 
development, and so in the US it will be inflected by 'opportunity', in Northern European corporatist countries inflected by equitable rewards for contributions to building a secure 'home for all' (or a welfare state that includes workers' rights). In India the barriers of clientelistic and patronage politics must be removed and in China the idea of communitarian moral deservingness can be broadened and made more inclusive. Similarly in Turkey where the inclusivity criteria for belonging among the faithful can be widened and democratic rights restored and strengthened.

Examples of such universalizing include the efforts towards universal health care in the US, policies of more open borders promoted especially among Green parties in Europe, campaigns for equal citizenship laws in India, more institutionalized democratic participation in China, and greater safeguards for secularism and democracy in Turkey. And it is not just democratic opposition and protest that have a role to play in countering populism and universalizing citizenship, but also concrete policies, such as institutionalizing fairness for competing parties, exposing false attribution of blame to elites and to domestic and foreign 'outsiders', and counting (and making the public aware of) the losses incurred by economic nationalism and welfare chauvinism or of religious or civilizational chauvinism or exclusionism - all these are ways of counting the costs of a lack of democracy.

Despite the variants in universalizing citizenship, countering populism is therefore neither Eastern or Western but could also be a globalizing pattern even if this is currently an uphill struggle. The tension in all cases, East and West, is to balance openness (of borders and economies and cultures) with diversity while at the same time maximizing the responsiveness of elites to people. To come back to the rival economistic or culturalist accounts of populism, there is an economic aspect to overcoming this tension, by means of more progressive and equitable taxation, which needs to take place via the state, in order to deepen and broaden social citizenship rights, as well as a cultural aspect, by way of extending greater tolerance or more civil and strengthening political rights - again, via the state. These suggested - political - ways of counteracting populism are small beginnings and lofty goals, but the arc of extending citizenship rights to fellow human beings, even if it has not run a straight course, may be bent, by means of struggle vis-à-vis states, towards global justice. 


\section{References}

Altinordu, A. 2021. "Uncivil populism in Power: The Case of Erdoganism", pp. 74-95 in Populism in the Civil Sphere, Alexander, J.; Kivisto, P. and Sciortino, G. (eds.), Cambridge: Polity Press.

Andersen, W. \& Damle, S. 2018. The Rss: A view to the inside. Delhi: Penguin Random House India.

Aydin, C. 2006. "Beyond civilization: Pan-Islamism, Pan-Asianism and the revolt against the west." Journal of Modern European History 4(2): 204-223.

Balıkçı, E. 2018. "What's Wrong with Institutions? A Short History of the Clash between IRAs and Turkish Populists", Populism, 1(2): 146-171.

Barkey, K. 2008. Empire of difference: The Ottomans in comparative perspective. Cambridge: Cambridge University Press.

Baykan, T. 2021. "The High-Low Divide in Turkish Politics and the Populist Appeal of Erdogan's Justice and Development Party". Pp. 199-222 in Populism in Global Perspective: A Performative and Discursive Approach. Ostiguy, P., Panizza, F. and Moffitt, B. (eds). Abingdon: Routledge.

Bayar, Y. 2019. "Roadblocks to Civility: Lessons from Turkish Nationalism", pp.79-99 in States, Nations, and Civility: Hallsian Perspectives, F. Duina (ed.). Toronto: University of Toronto Press.

Bayat, A. 2007. Making Islam democratic: Social movements and the post-Islamist turn. Stanford: Stanford University Press.

Bayly, C.A. 2018. Remaking the Modern World 1900-2015: Global Connections and Comparisons. Chichester: John Wiley \& Sons.

Cagaptay, S. 2020. Erdogan's Empire: Turkey's role in the Middle East. London: I.B. Tauris.

Chatterjee, E. 2020. "New developmentalism and its discontents: State activism in Modi's Gujarat and India", Development and Change, early view https://doi .org/10.1111/dech.12579.

Chatterjee, P. 2020. I am the People: Reflections on Popular Sovereignty Today. New York: Columbia University Press.

Economist. 2020. https:/www.economist.com/china/2020/03/12/a-proposal-to-help -a-few-foreigners-settle-in-china-triggers-a-furore.

Eisenstadt, S. 2020. "Multiple Modernities", Daedalus, 129 (1): 1-29.

El Amine, L. 2016. "Beyond East and West: Reorienting political theory through the prism of modernity." Perspectives on Politics, 14(1):102-120.

Fewsmith, J. 2008. China since Tiananmen: The Politics of Transition. Cambridge: Cambridge University Press.

Fukuyama, F. 2018. Identity: Contemporary Identity Politics and the Struggle for Recognition. London: Profile Books. 
Gerth, K. 2010. As China Goes, So Goes the World. New York: Hill and Wang.

Gries, P. 2004. China's New Nationalism: Pride, Politics, and Diplomacy. Berkeley: University of California Press.

Hadiz, V. 2016. Islamic Populism in Indonesia and the Middle East. Cambridge: Cambridge University Press.

Ionescu, G., and Gellner, E. (eds.) 1969. Populism. Its Meanings and National Characteristics. London: Weidenfeld \& Nicolson.

Hansen, T. 1999. The Saffron Wave: Democracy and Hindu Nationalism in Modern India. Princeton NJ: Princeton University Press.

Huntington, S. 1996. The Clash of Civilizations and the Remaking of World Order. New York: Simon and Schuster.

Ivaldi, G. and Mazzoleni, O. 2019. "Economic Populism and Producerism: European Right-Wing Populist Parties in a Transatlantic Perspective", Populism, 2(1): 1-28.

Jaffrelot, C. 2016. "The Hindu nationalist strategy of stigmatisation and emulation of 'threatening Others': an Indian style fascism?", pp. 17-30.in Politics of the 'Other' in India and China. Western Concepts in Non-Western Contexts. Koenig, L. and Chaudhuri, B. (eds). Abingdon: Routledge.

Jaffrelot, C. 2019. "Class and caste in the 2019 Indian election-Why so many poor have started to vote for Modi?" Studies in Indian Politics, 7(2):149-16o.

Judis, J. 2016. The Populist Explosion: How the Great Recession Transformed American and European Politics. New York: Columbia University Press.

Judis, J. 2018. The Nationalist Revival: Trade, Immigration, and the Revolt Against Globalization. New York: Columbia University Press, 2018.

Junker, A. 2021. "Left Populism in a Communist Civil Sphere", pp.232-50 in Populism in the Civil Sphere, Alexander, J.; Kivisto, P. and Sciortino, G. (eds.). Cambridge: Polity Press.

Kandil, H. 2016. The Power Triangle: Military, Security, and Politics in Regime Change. Oxford: Oxford University Press.

Kenny, P. 2017. Populism and Patronage: Why Populists Win Elections in India, Asia, and Beyond. Oxford: Oxford University Press.

Kuru, A.T. 2019. Islam, authoritarianism, and underdevelopment: A global and historical comparison. Cambridge: Cambridge University Press.

Lieven, D. 2002. Empire: The Russian empire and its rivals. London:John Murray.

Lindholm, C. 2002 (revised edn). The Islamic middle east: tradition and change. Oxford: Blackwells.

Maiorano, D. 2019. "The 2019 Indian Elections and the Ruralization of the BJP," Studies in Indian Politics, 7(2): 176-19o.

Mann, M. 1986. The Sources of Social Power, Volume I: A History of Power from the Beginning to 1760 AD. Cambridge: Cambridge University Press. 
Mann, M. 1988. "Ruling Class Strategies and Citizenship", pp. 188-209 in his States, War and Capitalism. Oxford: Basil Blackwell.

Mann, M. 2013. The Sources of Social Power vol. 4: Globalizations 1945-2011. Cambridge: Cambridge University Press.

Mehta, S. 2019. This Land is Our Land. An Immigrant's Manifesto. New York: Farrar, Straus and Giroux.

Mishra, P. 2012. From the Ruins of Empire: The Revolt Against the West and the Remaking of Asia. London: Allen Lane.

Mitter, R. 2004. A Bitter Revolution: China's Struggle with the Modern World. Oxford: Oxford University Press.

Mounk, Y. 2018. The People vs. Democracy: Why Our Freedom Is in Danger and How to Save It. Cambridge MA: Harvard University Press.

Mudde, C. 2007. Populist Radical Right Parties in Europe. Cambridge: Cambridge University Press, 2007).

Mudde, C. and Kaltwasser, C.R. 2017. Populism: A Very Short Introduction. Oxford: Oxford University Press.

Neyazi, T. 2018. Political communication and mobilisation: The Hindi media in India. Cambridge: Cambridge University Press.

Norris, P., \& Inglehart, R. 2019. Cultural backlash: Trump, Brexit, and authoritarian populism. Cambridge University Press.

Pappas, T. 2019. Populism and Liberal Democracy: A Theoretical and Comparative Analysis. (Oxford: Oxford University Press.

Przeworski, A. 2019. Crises of democracy. Cambridge: Cambridge University Press.

Rogenhofer, J.M. 2018. "Antidemocratic populism in Turkey after the July 2016 coup attempt", Populism, 1(2): 116-145.

Schroeder, R. 2013. An Age of Limits: Social Theory for the 21st Century. Basingstoke: Palgrave Macmillan.

Schroeder, R. 2019. "The Dangerous Myth of Populism as a Thin Ideology", Populism, 3(1): 13-28.

Schroeder. R. 2020. "Political Power and the Globalizing Spread of Populist Politics", Journal of Political Power, 13 (1): 22-40.

Shi-Kupfer, K., Ohlberg, M., Lang, S., \& Lang, B. 2016. "Ideas and Ideologies Competing for China's Political Future." Mercator Institute for China Studies, 5(12).

Stanley, B. 2008. “The Thin Ideology of Populism." Journal of Political Ideologies 13(1): 95-110.

Tang, W. 2016. Populist Authoritarianism: Chinese Political Culture and Regime Stability.

New York: Oxford University Press.

Tugal, C. 2016. The Fall of the Turkish Model. London: Verso.

Turner, B. 1986. Citizenship and Capitalism. London: Allen and Unwin. 
Westad, O.A. 2005. The Global Cold War. Cambridge: Cambridge University Press.

Weiss, J.C. 2019. "How hawkish is the Chinese public? Another look at "rising nationalism" and Chinese foreign policy", Journal of Contemporary China, 28(119): 679-695. Wright, T. 2028. Popular Protest in China. Cambridge: Polity Press.

Xiang, L. 2020. The Quest for Legitimacy in Chinese Politics: A New Interpretation. Abingdon: Routledge.

Zhao, S. 2004. A Nation-State by Construction: Dynamics of Modern Chinese Nationalism. Stanford: Stanford University Press.

Zhang, C. 2019. "Right-wing populism with Chinese characteristics? Identity, otherness and global imaginaries in debating world politics online," European Journal of International Relations, 2019. https://doi.org/10.1177/1354066119850253. 